\title{
A New Endoscopic Surgical Classification and Invasion Criteria for Pituitary Adenomas Involving the Cavernous Sinus
}

\author{
Kavernöz Sinüsü Tutan Hipofiz Adenomlarında Yeni Bir Endoskopik \\ Cerrahi Sinflandirma ve Invazyon Kriterleri
}

Savas CEYLAN, Ihsan ANIK, Kenan KOC

Kocaeli University, Faculty of Medicine, Department of Neurosurgery and Pituitary Research Centre, Kocaeli, Turkey

Correspondence address: Savas CEYLAN / E-mail: ssceylan@yahoo.com

\begin{abstract}
AIM: There are two major problems for the pituitary adenomas invading the Cavernous Sinus (CS); differentiation of extension and invasion and inability to demonstrate the medial wall via preoperative imaging methods. Two important corridors are defined in endoscopic cavernous sinus approaches; the lateral and medial corridor.

MATERIAL and METHODS: A retrospective analysis was performed in 400 endoscopic transphenoidal approaches and 360 pituitary adenomas underwent endoscopic transphenoidal surgery in our department between September 1997 and December 2010. 48 patients affected by the tumours involving the cavernous sinus were included in this study.

RESULTS: We performed an intraoperative evaluation of cavernous sinus invasion considering visualization of the medial wall defect, intracavernous ICA segments, minor tumour extensions through small focal pit holes of the medial wall of CS or confirming carotid segments of CS by micro-doppler. Cavernous sinus involvement was classified into three types according to the medial and lateral corridor extension of the tumor as 25 isolated medial corridor involvement (Type I), 5 isolated lateral corridor involvement (Type II) and 18 total involvement (Type III).

CONCLUSION: Our classification depends on fully surgical endoscopic approach supported by neuroimaging techniques and anatomical studies and shows a good predictive value for all cavernous sinus involvement.
\end{abstract}

KEYWORDS: Endoscope, Pituitary adenoma, Cavernous sinus, Transphenoidal approach

öz

AMAÇ: Kavernöz sinüsü invaze eden hipofiz adenomları için iki önemli sorun vardır; ekstansiyonla invazyonun ayrılması ve preoperatif görüntüleme yöntemleriyle medial duvarın gösterilememesi. Endoskopik kavernöz sinus yaklaşımlarında iki önemli koridor tanımlanmıştır; lateral ve medial koridorlar.

YÖNTEM ve GEREÇ: Kliniğimizde Eylül 1997 ile Aralık 2010 tarihleri arasında 400 endoskopik transsfenoidal yaklaşım içinde ameliyat edilen 360 hipofiz adenomu retrospektif olarak değerlendirilmiştir. Çalışmaya kavernöz sinüsü de tutan tümörlü 48 olgu dahil edilmiştir.

BULGULAR: Kavernöz sinus invazyonunu intraoperatif olarak medial duvar defektini, intrakavernöz carotid arter segmentlerini, kavernöz sinus medial duvarındaki küçük defektleri görüntüleyerek ya da mikrodopler ile kavernöz sinüsün karotid segmentlerini konfirme ederek sağladık. İnvazyonu tanımladıktan sonra kavernöz sinüse yayılım şeklini tümörün medial ve lateral koridorlardan ilerlemesine göre üç grupta sınıflandırdık.25 hastada izole medial koridor tutulumu (Tip I), 5 hastada lateral koridor tutulumu (Tip II) ve18 hastada da her iki koridor tutulumu saptadık (Tip III).

SONUÇ: Yapmış olduğumuz sınıflandırma anatomik çalışmalarla ve görüntüleme yöntemleriyle desteklenmiş bir endoskopik cerrahi sınıflandırmadır ve sadece yüksek dereceli değil, tüm kavernöz sinus tutulumları için prediktif değer taşımaktadır.

ANAHTAR SÖZCÜKLER: Endoskop, Hipofiz adenomu, Kavernöz sinüs, Transfenoidal yaklaşım 


\section{INTRODUCTION}

Pituitary adenomas usually compress surrounding structures, commonly resulting in sella enlargement and suprasellar extension. Extended microscopic and endoscopic approaches for the cavernous sinus (CS) invasion have been reported in the literature $(4,5,6,11,12,17,21,22)$.

Surgical approaches to the cavernous sinus, whether transcranial or inferomedial are still challenges. In recent studies, increases in the rate of pituitary adenomas invading the CS (15-20\%) are reported $(18,20)$.

Contrary to detailed anatomic studies of the cavernous sinus shown by endoscopic approaches, endoscopic clinical studies demonstrating cavernous sinus invasion are limited $(1,2,3,4,7,13,19,20,21,22,23)$.

Numerous studies have dealt with the predictive value of preoperative neuroimaging of cavernous sinus invasion (10, 24,31). However, all these studies are based on the relation among pituitary adenoma with CS, ICA and venous sinuses demonstrated by preoperative MRI studies.

Recent neuroimaging techniques cannot demonstrate the medial wall of the CS and these classifications also cannot define inferomedial cavernous sinus invasion. Among these widely used classifications due to confirmation of surgical findings with a conventional microscope, invasion is not seen in especially grade 2 lesions and some grade 3 lesions by the endoscopic technique. The most efficient technique for visualization of the cavernous sinus medial wall is the endoscopic technique.

The endoscopic approach also has an important role in surgically defining and differentiating displacement or invasion of the cavernous sinus by pituitary adenoma. The endoscopic technique is a more favourable method than the microscopic technique in defining cavernous sinus invasion.

The aim of this study was to define cavernous sinus invasion criteria and endoscopic classification of cavernous sinus invasion pathways of the adenomas.

This classification was based on two important corridors, the medial and lateral corridors that have been defined in anatomic and clinic studies (3).

\section{MATERIAL and METHODS}

A retrospective analysis was performed on 400 endoscopic transphenoidal approaches and 360 pituitary adenomas that underwent endoscopic transphenoidal surgery in our department between September 1997 and December 2010.

48 patients, 23 female ( $48 \%$ ) and 25 male (52\%), affected by the tumours involving the cavernous sinus and treated for the last 9 years were included in this study. Ages ranged from 11 to 70 (mean 42.48) years. Follow-up was between 1 month and 78 months (mean 34.37 months) (Table I).

Pituitary adenomas were histologically and immunohistochemically investigated. They were classified as functioning (GH (n: 22), PRL (n: 7) and ACTH (n: 6) secreting adenomas) or non-functioning adenomas (n: 13) in relation to the clinical activity.

Preoperative MRI findings were assessed according to Knosp classification.

The extent of resection was evaluated based on MR Images obtained in the immediate postoperative period and again 3 months afterwards. The extent of resection was determined as the radical, subtotal (the clear presence of residual tumour but with resection of $>80 \%$ of the tumour), or partial (the clear presence of residual tumour but with resection of $<80 \%$ of the tumour). Tumour pathologic type was confirmed by the Department of Pathology.

\section{Surgical Approach}

We performed previously defined cavernous sinus approaches in our first 14 cases including the paraseptal approach, middle turbinectomy and contralateral middle turbinectomy $(3,21,22)$.

Recently defined extended approaches were performed in 2 patients and combined approaches for 32 patients. In combined approaches, the surgeries were performed via a binostril approach with enlarged anterior sphenoidotomy allowing wide exposure and easier surgical maneuver. After medial pterygoid process resection, wide sellar floor opening expanding more laterally to the cavernous sinus was performed. In this part of the approach, a Kerrison rongeur was used to widen the sellar floor through the cavernous sinus and following the dissection of this part of the dura, surgical micro-scissors were used rather than a surgical blade to enlarge the dura. This avoids redundant carotid artery injury (Figure 1A,B). After removal of the sellar component of the tumor, the invasive part of the lesion was resected according to whether the medial or lateral corridor or both corridors were involved.

\section{Intraoperative Cavernous Sinus Involvement Classification}

We performed an intraoperative evaluation of cavernous sinus invasion considering;

1. Visualization of the medial wall defect (Figure $2 A-C$ ).

2. Visualization of at least one of the intracavernous ICA segments (anterior vertical, horizontal, posterior bend, paraclival carotid artery) (Figure $3 \mathrm{~A}-\mathrm{C}$ ).

3. Visualization of minor tumoral extensions through small focal pit holes of the medial wall of CS (Figure 4A-C).

4. Carotid artery segments were confirmed by micro doppler and CS invasion was evaluated during the tumor removal in cases of inability to view the carotid segments of CS endoscopically due to CS hemorrhage (Figure 5A-C).

After identifying cavernous sinus invasion, cavernous sinus involvement is classified into three types according to the medial and lateral corridor extension of the tumor. 


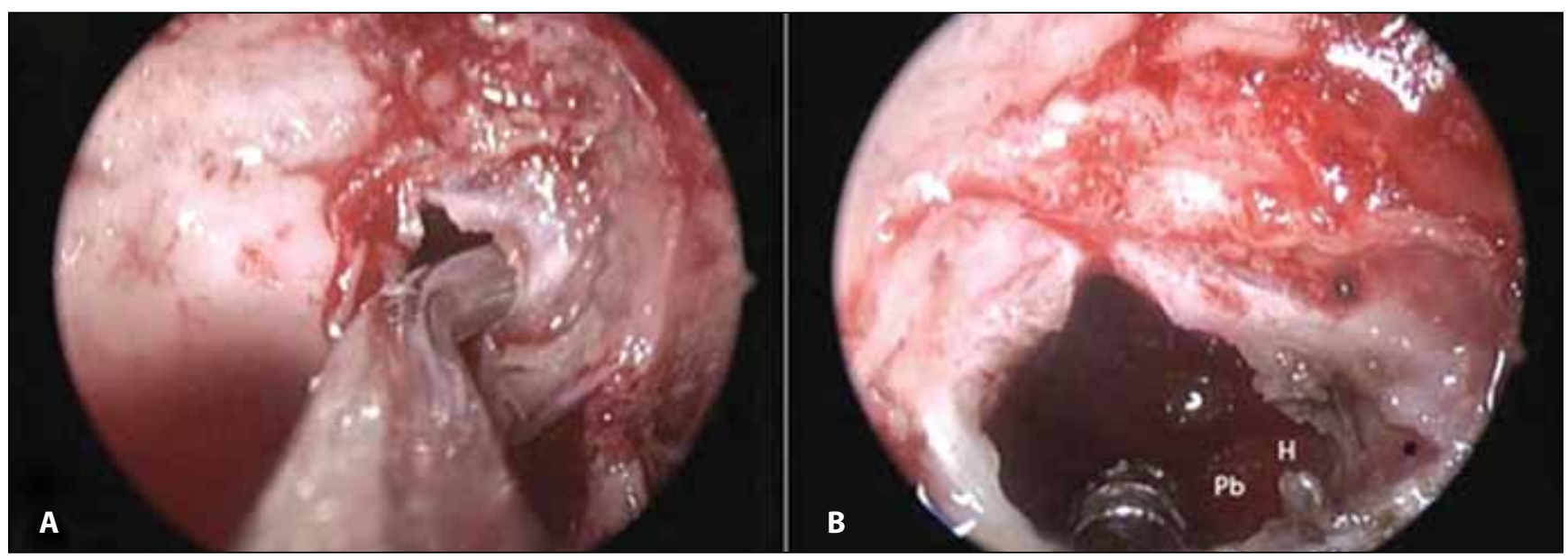

Figure 1: Case 31: 18 year-old female with GH secreting adenoma. A, B) Sellar floor was expanded through the cavernous sinus by Kerrison rongeur and after dissection of this part of dura, surgical micro-scissor was used rather than the surgical blade to enlarge after controlling by aspirator or micro-hook. This avoids redundant carotid artery injury.

*: Carotid Artery underlying the dura, H: Horizontal Segment of the Cavernous Carotid Artery, Pb: Posterior Bend of the Cavernous Carotid Artery.

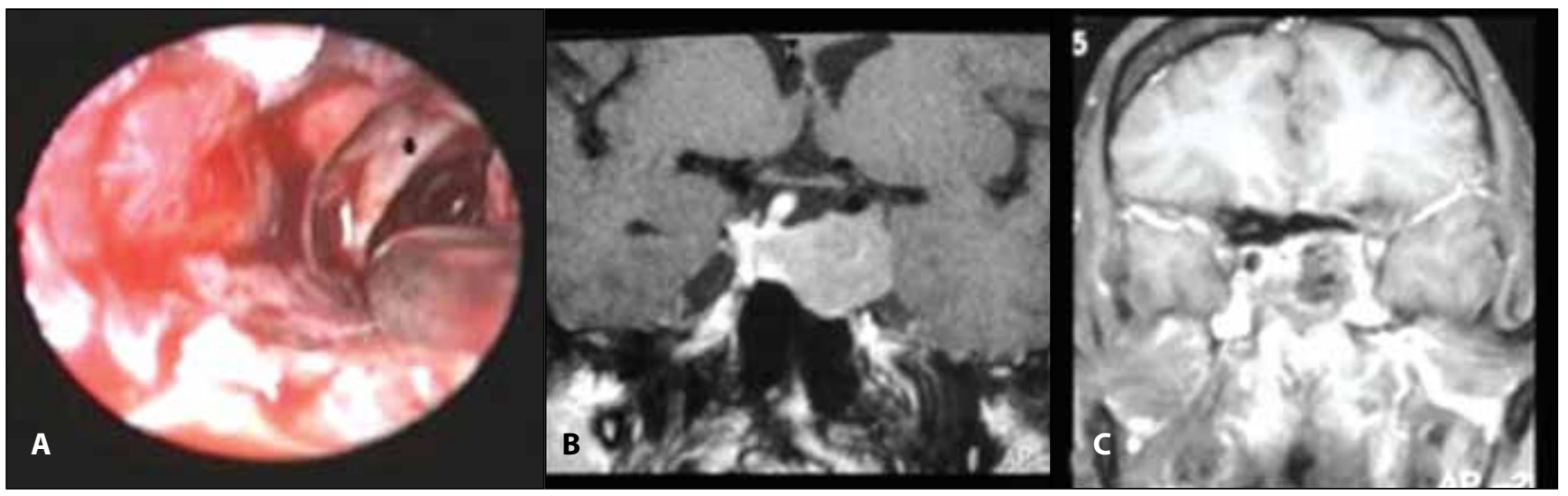

Figure 2: Case 24: 39 year-old male with GH secreting adenoma. A) Intraoperative visualization of the medial wall defect. Preoperative B) and Postoperative C) Gd-enhanced, T1-weighted MR images of the patient.

*: Cavernous Sinus Medial Wall.

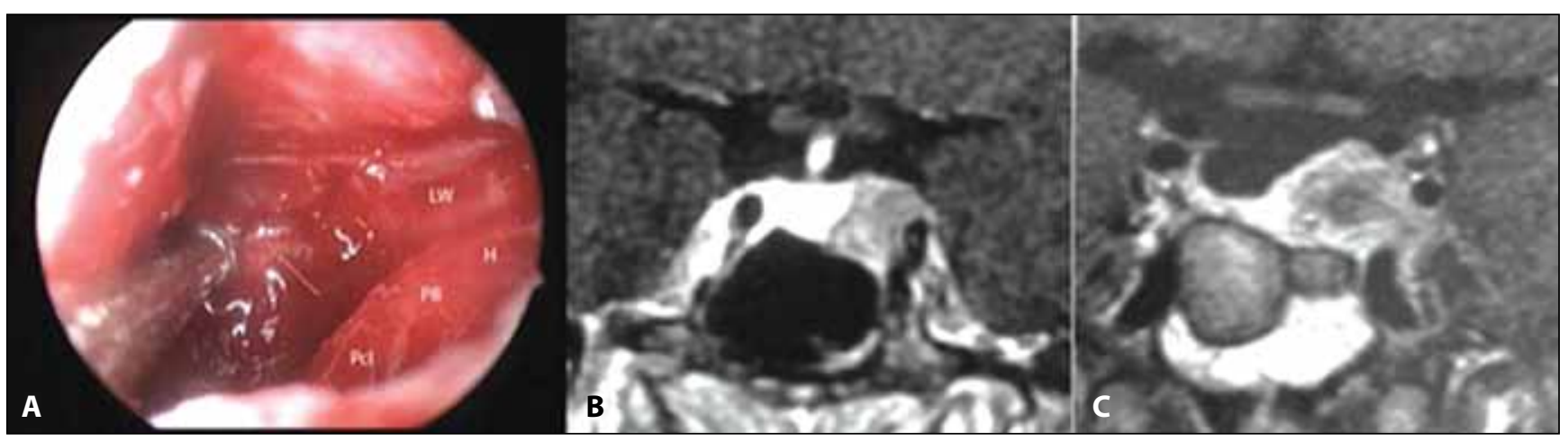

Figure 3: Case 31: 18 year-old female with GH secreting adenoma. A) Visualization of intracavernous ICA segments. Preoperative B) and Postoperative C) Gd-enhanced, T1-weighted MR images of the patient.

LW: Lateral Wall, H: Horizontal Segment of the Cavernous Carotid Artery, Pb: Posterior Bend of the Cavernous carotid Artery, Pcl: Paraclival Carotid Artery. 


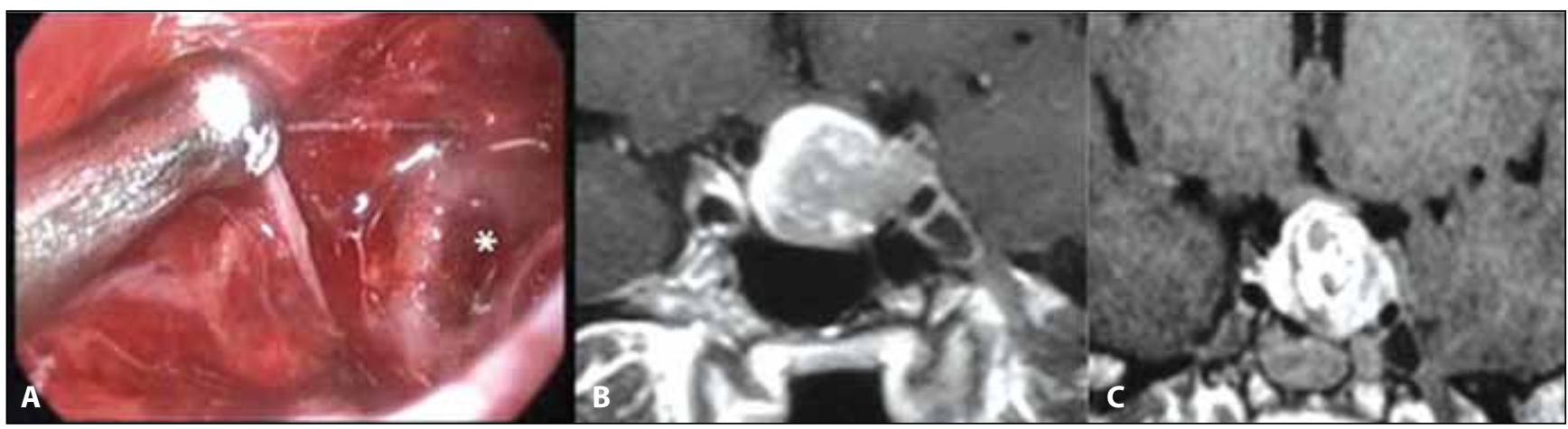

Figure 4: Case 29: 40 year-old female with GH secreting adenoma. A) Visualization of minor tumoral extensions through small focal pit-holes of the medial wall of CS. Preoperative B) and Postoperative C) Gd-enhanced, T1-weighted MR images of the patient. *: Focal pit-hole.

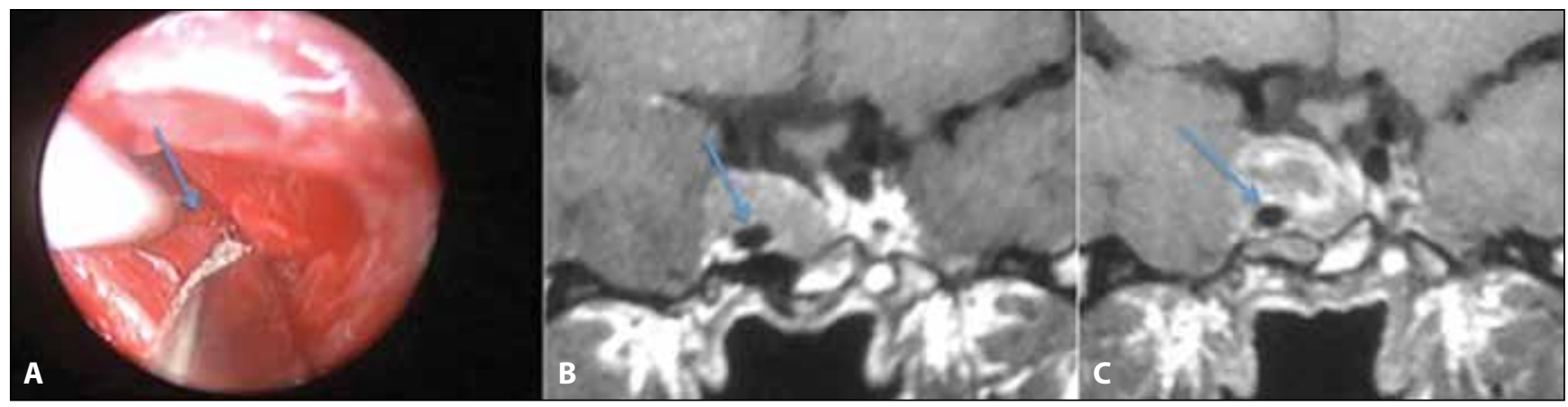

Figure 5: Case 14:28 year-old female with GH secreting adenoma A) In case of inability to view the CS endoscopically due to hemorrhage, carotid artery segments were confirmed by microdoppler and CS invasion was evaluated. Preoperative B) and Postoperative C) Gdenhanced, T1-weighted MR images of the patient.

Blue Arrows: Segment of carotid Artery.

Type 1 ; isolated medial corridor involvement (Figure 6A).

Type 2; isolated lateral corridor involvement (Figure 6B)

Type 3; total involvement (both medial and lateral corridor involvement) (Figure 6C).

\section{RESULTS}

Considering this classification, there were 25 isolated medial corridor involvement (Type I), 5 isolated lateral corridor involvement (Type II) and 18 total involvement (Type III) cases.

Among 48 patients with CS invasion, 43 patients were grade 3-4 according to the Knosp classification. Minor tumour extension was observed in 2 patients with grade 3 . Gr 2 was not defined in any patient. 5 patients, who could not be evaluated according to Knosp classification, were defined as isolated lateral corridor.

During the intraoperative assessment, group 2 ,which is defined as visualization of at least one of the ICA segments, was the most commonly seen criteria with 29 patients, and group 3, which is defined as visualization of minor tumour extension through small focal pit holes of the medial wall, was the least common with 3 patients according to cavernous sinus invasion criteria.
25 patients with type 1 , isolated medial corridor, 5 patients with type 2 , isolated lateral corridor and 18 patients with type 3 , total lesions were evaluated according to the involvement of the corridors.

\section{DISCUSSION}

There are two major problems with pituitary adenomas invading CS. The first is to define extension and invasion. In this study, cavernous sinus invasion criteria were defined endoscopically. Invasion is identified and extension is distinguished according to these criteria. Invasion of the cavernous sinus on one side and extension to the cavernous sinus on the other side were clearly demonstrated by the endoscopic approach in the same case in one of our patients (Figure 7A-C).

The second problem is the difficulty in demonstrating medial wall via preoperative imaging modalities. There is no neuroimaging method that can show the medial wall precisely. In the literature, different results of the anatomic studies have been published about the structure of the CS medial wall. Studies on the structure of the medial wall were reported as one layer by some authors, as two layers in another or thin, loose and histological defects by the other 


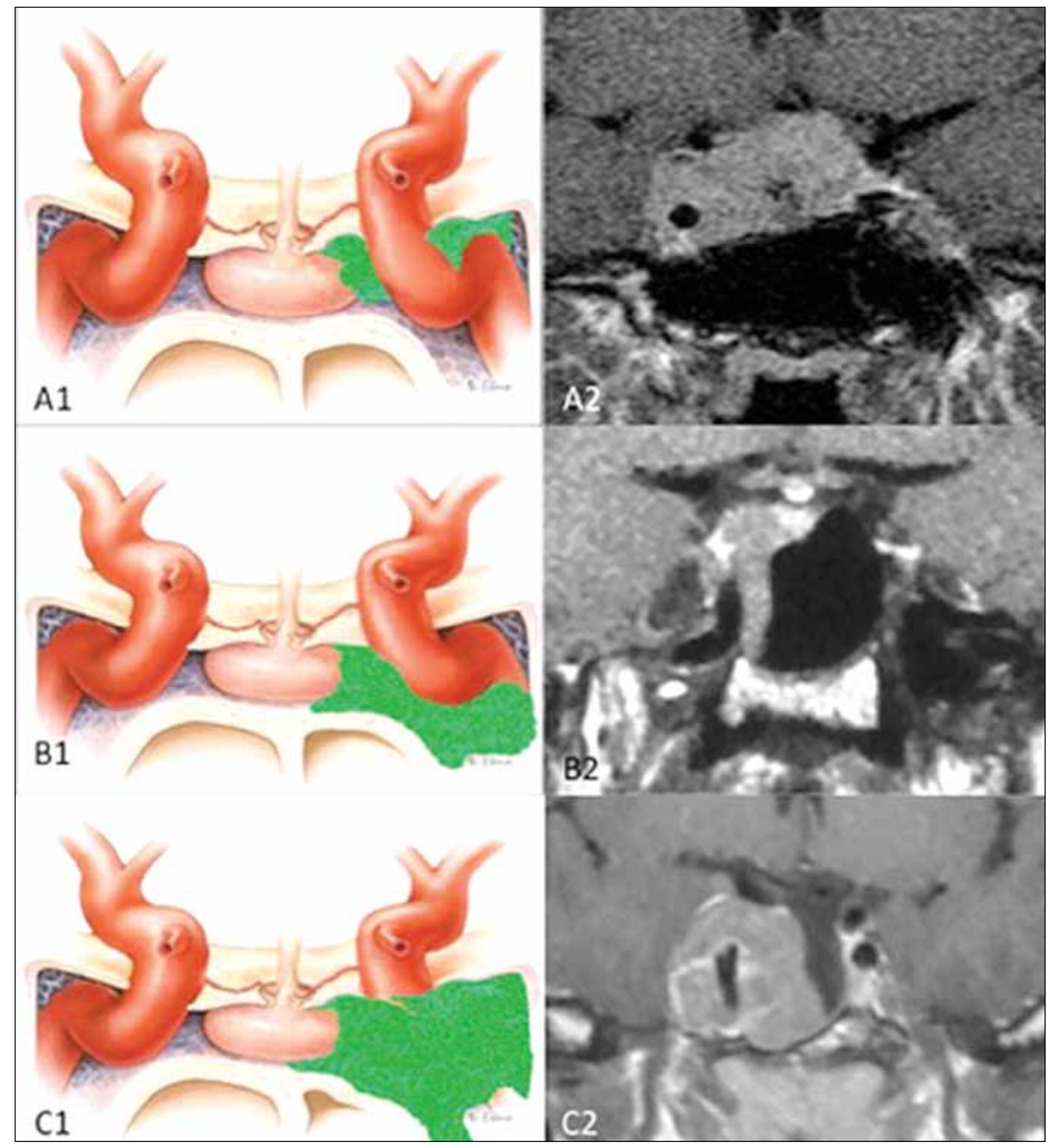

Figure 6: A) Case 36: 28 year-old male with GH secreting adenoma. A1: Illustrated drawing of Type 1; isolated medial corridor involvement, A2: Correspondent Preoperative Gd-enhanced, T1-weighted MR images.

B) Case 12: 25 year-old male with GH secreting adenoma. B1: Illustrated drawing of Type 2; isolated lateral corridor involvement, B2: Correspondent Preoperative Gd-enhanced, T1-weighted MR images.

C) Case 11: 55 year-old female with GH secreting adenoma. C1: Illustrated drawing of Type 3; total (both medial and lateral corridors) involvement, C2: Correspondent Gd-enhanced, T1-weighted MR images. 

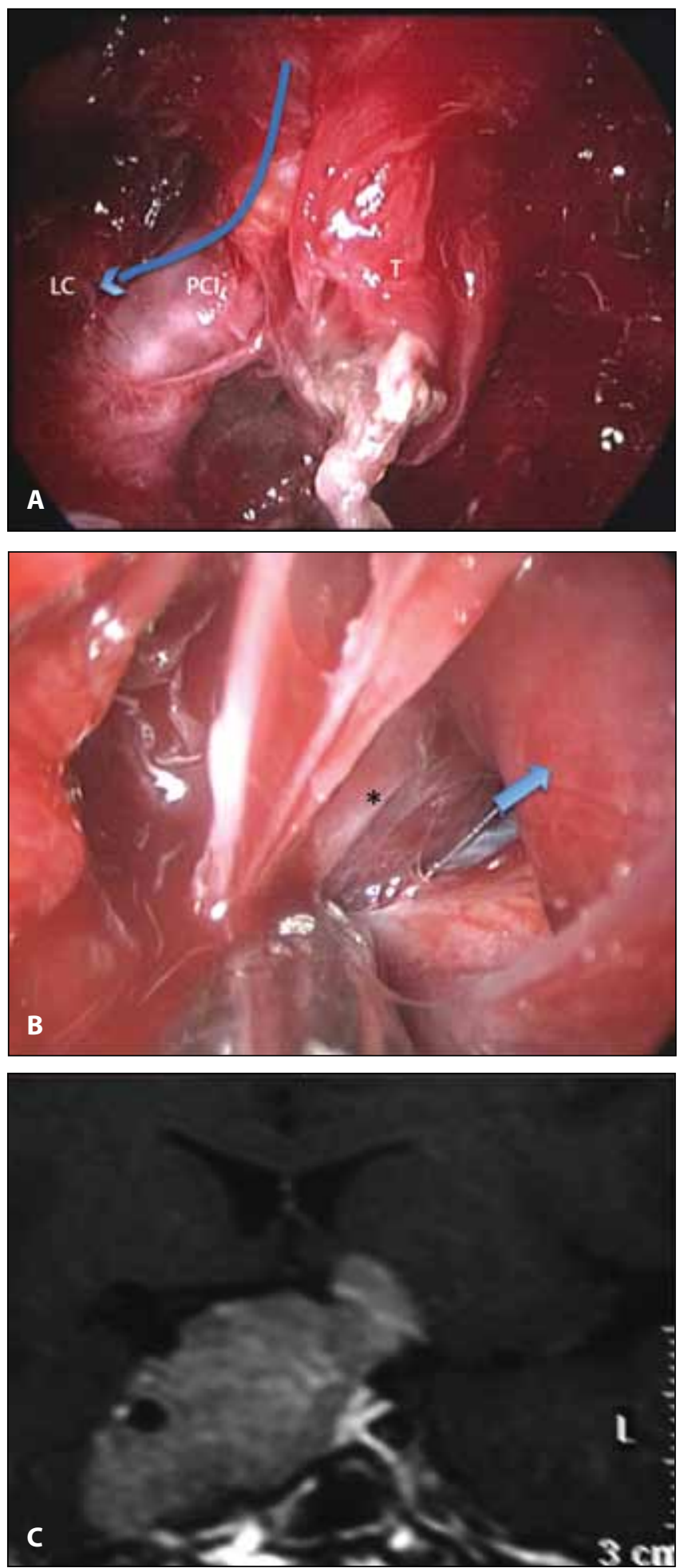

Figure 7: Case 32: 44 year-old male with nonsecretory adenoma A) Invasion on one side and displacement B) on the other side were seen in the same case and was excellently viewed by the endoscopic technique. C) Preoperative Gd-enhanced, T1weighted MR images of the patient.

LC (long arrow): Lateral Corridor, Pcl: Paraclival Carotid Artery, T: Fibrotic Tumor, Short blue arrow: Supradiaphragmatic Ophthalmic Segment, Short arrow: ICA authors $(8,9,14,15,26,28,30)$. Thus, some authors reported that tumour histology is responsible for CS invasion while some authors insist on histological defects of the medial wall $(15,16,25,27,29)$.

In our previously reported study, we encountered invasion through fragile points of the medial wall only in one case with non-functional adenoma (7).

We observed that medial wall kept its integrity in cases without cavernous sinus involvement. Furthermore in one case the cavernous components of pituitary adenoma were removed from the thick fibrous membrane and fibrin trabeculation of the medial wall in CS as Songtao et al (26) defined (Figure 8A-C).

Two important corridors are defined in endoscopic cavernous sinus approaches (3). The ICA medial corridor is formed by the $C$-shaped segment of the intracavernous sinus - carotid artery and is bordered posteriorly by the dorsum sella and posterior petroclinoid fold. The lateral corridor to the ICA (triangular area) is delineated by the intracavernous track of the internal carotid posteriorly, by the vidian nerve inferiorly and by the medial pterygoid process anteriorly (3).

We have demonstrated these corridors via the endoscopic approach in our previously published clinical series (7). Pituitary adenomas create an entry through these corridors, and we have used the same pathway as surgical corridors (Figure 9A-D).

Cavernous sinus invasion of pituitary adenomas most often progresses through the medial corridor as reported in clinical series $(7,19,20,23)$.

In recently published anatomic studies, it is reported that the superior part of the medial wall was thinner while the inferior part thicker $(25,26)$. This confirms why pituitary adenomas are usually located at the medial corridor and demonstrate CS invasion through the superior part. Thus, this part is named 'the natural gate' in CS surgery (26).

In our series, although isolated medial corridor involvement was seen in 25 cases, isolated lateral corridor involvement was encountered in 5 cases. Total involvement was present in 18 cases. Less frequently seen isolated lateral corridor involvement is not defined fully in the Knosp classification. Cottier et al (10) defined the carotid sulcus venous compartment and inferolateral venous compartment, which form only a part of the isolated lateral corridor emphasized in our classification. Alfieri et al (1) demonstrated the cavernous sinus subdividing into two portions through the endoscopic approach as paraclival ICA and parasellar ICA in their anatomic study. They exposed the paraclival ICA into two parts; the lacerum segment and trigeminal segment.The lateral corridor defined in our classification is formed by the carotid sulcus venous and inferolateral venous compartments described by Cottier et al (10), and the trigeminal segment demonstrated by Alfier et al (1) in their anatomic study. 
Table I: Summary of Clinical and Surgical Information in 48 Patients with Adenomas

\begin{tabular}{|c|c|c|c|c|c|c|c|c|}
\hline PN & A/G & $\begin{array}{l}\text { Hist. } \\
\text { Type }\end{array}$ & Knosp & IOE & ESC & Surg. $\mathbf{A}$ & Res.V. & $\begin{array}{l}\text { Follow } \\
\text {-up (M) }\end{array}$ \\
\hline 1 & $44 / F$ & $\mathrm{GH}$ & 4 & 2 & Type I & MT & SubT & 78 \\
\hline 2 & $42 / \mathrm{M}$ & PRL & 4 & 2 & Type III & PS & Radical & 77 \\
\hline 3 & $11 / \mathrm{F}$ & ACTH & 4 & 2 & Type III & $\begin{array}{l}\text { Cont } \\
\text { MT }\end{array}$ & SubT & 72 \\
\hline 4 & $50 / \mathrm{M}$ & ACTH & 3 & 4 & Type I & PS & Radical & 71 \\
\hline 5 & $21 / F$ & NS & 3 & 4 & Type I & PS & SubT & 68 \\
\hline 6 & $65 / M$ & NS & 4 & 1 & Type I & MT & SubT & 67 \\
\hline 7 & $53 / \mathrm{M}$ & $\mathrm{GH}$ & 4 & 2 & Type I & MT & SubT & 65 \\
\hline 8 & $62 / \mathrm{M}$ & NS & 3 & 1,2 & Type I & MT & Radical & 65 \\
\hline 9 & $56 / M$ & ACTH & 4 & 2 & Type III & MT & Radical & 64 \\
\hline 10 & $53 / \mathrm{F}$ & $\mathrm{GH}$ & Ventr & 1 & Type II & PS & Radical & 64 \\
\hline 11 & $55 / F$ & $\mathrm{GH}$ & 3 & 2 & Type III & MT & Radical & 62 \\
\hline 12 & $25 / \mathrm{M}$ & $\mathrm{GH}$ & Ventr & 1 & Type II & PS & Radical & 51 \\
\hline 13 & $49 / \mathrm{M}$ & $\mathrm{GH}$ & 3 & 1 & Type I & MT & Radical & 51 \\
\hline 14 & $28 / F$ & $\mathrm{GH}$ & 4 & 2 & Type I & PS & Radical & 51 \\
\hline 15 & $43 / F$ & PRL & 4 & 2 & Type III & Ext & SubT & 50 \\
\hline 16 & $54 / \mathrm{M}$ & NS & 3 & 1,2 & Type I & Ext & Radical & 59 \\
\hline 17 & $25 / F$ & PRL & 4 & 2 & Type III & Comb & Radical & 59 \\
\hline 18 & $36 / \mathrm{M}$ & ACTH & 3 & 2 & Type I & Comb & Radical & 59 \\
\hline 19 & $70 / F$ & NS & 4 & 2 & Type I & Comb & SubT & 59 \\
\hline 20 & $42 / \mathrm{F}$ & PRL & 3 & 3 & Type I & Comb & Radical & 48 \\
\hline 21 & $39 / \mathrm{F}$ & ACTH & Ventr & 1 & Type II & Comb & Radical & 42 \\
\hline 22 & $53 / \mathrm{M}$ & NS & 4 & 2 & Type III & Comb & SubT & 39 \\
\hline 23 & $57 / \mathrm{F}$ & $\mathrm{GH}$ & Ventr & 4 & Type II & Comb & Radical & 25 \\
\hline 24 & $39 / \mathrm{M}$ & GH & 4 & 1 & Type I & Comb & Radical & 30 \\
\hline
\end{tabular}

\begin{tabular}{|c|c|c|c|c|c|c|c|c|}
\hline PN & $A / G$ & $\begin{array}{l}\text { Hist. } \\
\text { Type }\end{array}$ & Knosp & IOE & ESC & Surg. $A$ & Res.V. & $\begin{array}{l}\text { Follow } \\
\text {-up (M) }\end{array}$ \\
\hline 25 & $48 / F$ & PRL & 4 & 2 & Type III & Comb & Radical & 29 \\
\hline 26 & $35 / \mathrm{M}$ & GH & 4 & 2 & Type III & Comb & Radical & 28 \\
\hline 27 & $42 / \mathrm{M}$ & GH & 4 & 1,2 & Type I & Comb & Radical & 27 \\
\hline 28 & $24 / M$ & NS & 4 & 1 & Type III & Comb & SubT & 18 \\
\hline 29 & $40 / \mathrm{F}$ & GH & 3 & 3 & Type I & Comb & Radical & 18 \\
\hline 30 & $46 / F$ & GH & 3 & 4 & Type I & Comb & Radical & 18 \\
\hline 31 & $18 / \mathrm{F}$ & GH & 3 & 2 & Type III & Comb & Radical & 17 \\
\hline 32 & $44 / \mathrm{M}$ & NS & 4 & 2 & Type III & Comb & Radical & 16 \\
\hline 33 & $56 / F$ & ACTH & 3 & 4 & Type III & Comb & SubT & 14 \\
\hline 34 & $45 / F$ & NS & 4 & 2 & Type III & Comb & Radical & 13 \\
\hline 35 & $36 / \mathrm{M}$ & NS & 3 & 2 & Type I & Comb & Radical & 10 \\
\hline 36 & $28 / \mathrm{M}$ & $\mathrm{GH}$ & 4 & 2 & Type I & Comb & SubT & 10 \\
\hline 37 & $34 / \mathrm{M}$ & GH & Vent & 4 & Type II & Comb & Radical & 9 \\
\hline 38 & $36 / \mathrm{M}$ & PRL & 4 & 2 & Type III & Comb & SubT & 9 \\
\hline 39 & $63 / F$ & NS & 4 & 2 & Type III & Comb & Radical & 8 \\
\hline 40 & $27 / M$ & GH & 3 & 2 & Type I & Comb & Radical & 8 \\
\hline 41 & $27 / \mathrm{F}$ & $\mathrm{GH}$ & 3 & 2 & Type I & Comb & Radical & 7 \\
\hline 42 & $41 / \mathrm{M}$ & GH & 3 & 3 & Type III & Comb & Radical & 7 \\
\hline 43 & $41 / F$ & GH & 4 & 3 & Type I & Comb & Radical & 6 \\
\hline 44 & $54 / \mathrm{F}$ & NS & 3 & 4 & Type I & Comb & Radical & 5 \\
\hline 45 & $57 / \mathrm{M}$ & NS & 3 & 2 & Type I & Comb & Radical & 4 \\
\hline 46 & $22 / \mathrm{M}$ & PRL & 4 & 2 & Type III & Comb & SubT & 3 \\
\hline 47 & $47 / \mathrm{M}$ & $\mathrm{GH}$ & 3 & 2 & Type I & Comb & Radical & 2 \\
\hline 48 & $29 / F$ & $\mathrm{GH}$ & 3 & 1 & Type I & Comb & Radical & 1 \\
\hline
\end{tabular}

Cont MT: Contralateral Middle Turbinectomy, MT: Middle Turbinectomy, PRL: Prolactinoma, Knosp Parasellar Extension Grade, IOE: Intraoperative Evaluation, ESC: Endoscopic Surgical Confirmation.

We analyzed our cases according to the Knosp classification using the endoscopic technique. Cavernous sinus invasion was not seen especially in grade 2 cases (Figure 10A-C) and in three cases with grade 3 lesions; invasion developed through the pit holes (Figure 4A-C).

Frank et al published the only classification study on CS invasion via the endoscope $(19,20)$. This classification contains 5 grades. Grade 2 and over are accepted as CS invasion as follows: Grade 2 is focal extension through one or more little pit holes. Grade 3 is multifocal invasion without encasement of ICA. Grade 4 is total encasement of the ICA.

Frank et al (19) used two different surgical approaches for pituitary adenomas involving the cavernous sinus including the classic functional endoscopic pituitary surgery (FEPS) or the ethmoid-pterygoidsphenoidal endoscopic approach (EPSea). The operations were usually performed through one nostril, which was the one with the larger cavity in FEPS and homolateral to the involved cavernous sinus in EPSea $(19,20)$.

We performed a binostril approach for the last 34 cases in this series, without the need of a far lateral approach and providing more maneuverability.

In this study, the most significant hemorrhage was encountered in cases with an isolated lateral corridor. In three of five cases, profuse hemorrhage was seen during the inferolateral extension of the sellar opening. CS hemorrhage was mostly seen in this group of series. Venous sinuses are compressed and obliterated by the lesion in total involvement cases. A venous bleed can start after lesion removal when the sinuses are decompressed. In isolated lateral corridor involvement, the sinuses are not totally compressed. Therefore, profuse bleeding can be encountered in the beginning. 

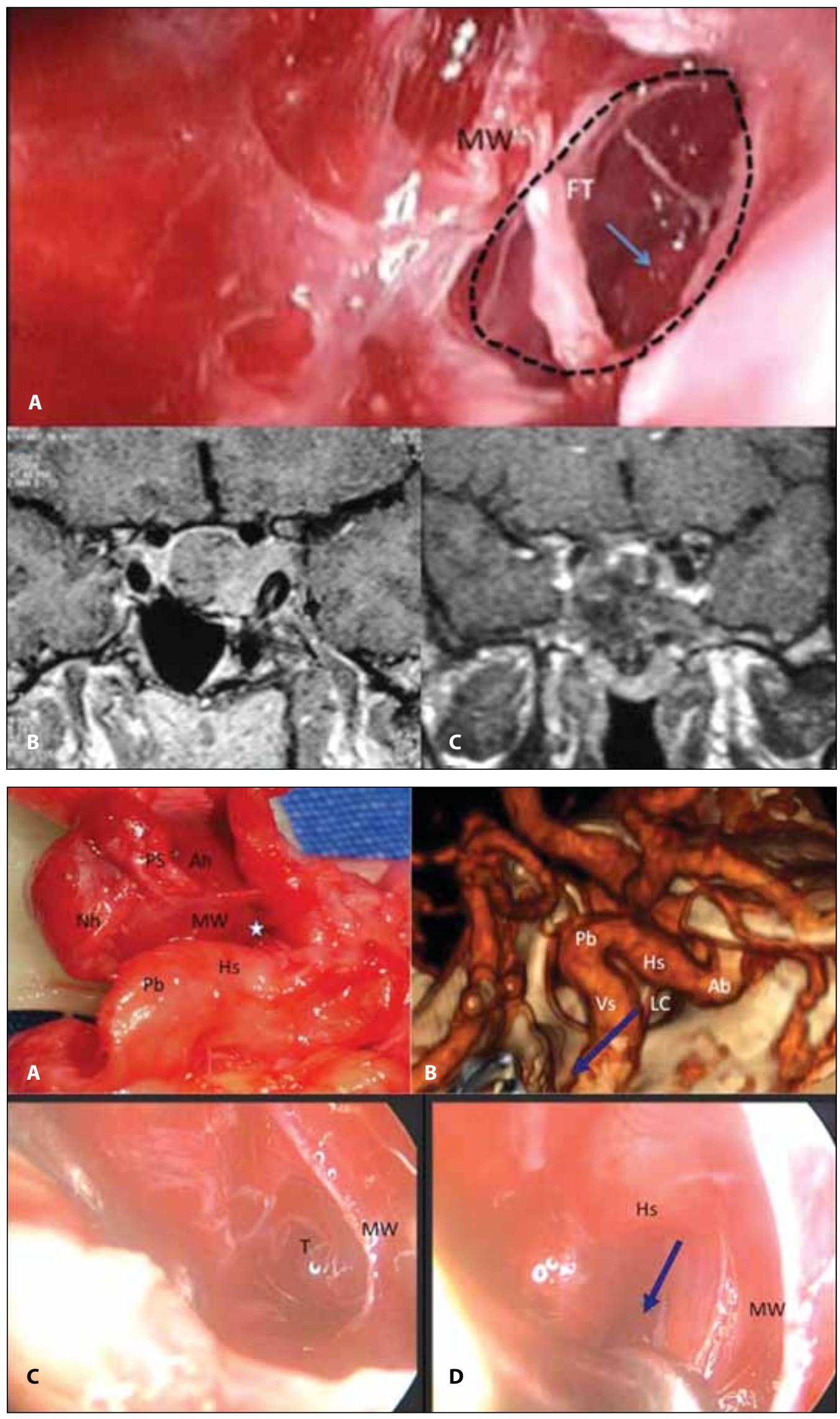

Figure 8: Case 27: 42 yearold male with $\mathrm{GH}$ secreting adenoma.

A) Cavernous component of pituitary adenoma was removed from the thick fibrous membrane and fibrous trabeculation of medial wall in CS.

Preoperative

B) and postoperative C) Gd-enhanced, T1weighted MR images of the patient.

MW: Medial wall of the Cavernous Sinus,

FT: Fibrous Trabeculation *: Horizantal Segment of Cavernous Carotid Artery, Blue Arrow: Posterior bend of the Cavernous Carotid Artery.

Figure 9: The relation between the hypophysis, medial wall, corridors and carotid artery segments. A) A cadaveric specimen, B) CT Angiography, C,D) Intraoperative view during the surgical removal of the adenoma.

PS: Pituitary Stalk,

Nh: Neurohypophysis,

Ah: Adenohypophysis, MW: Medial Wall, Pb: Posterior Bend of Cavernous Carotid Artery, Hs: Horizantal Segment of Cavernous Carotid Artery, Vs: Vertical Segment of Cavernous Carotid Artery, Star: Medial Corridor, LC: Lateral Corridor (blue arrow) 


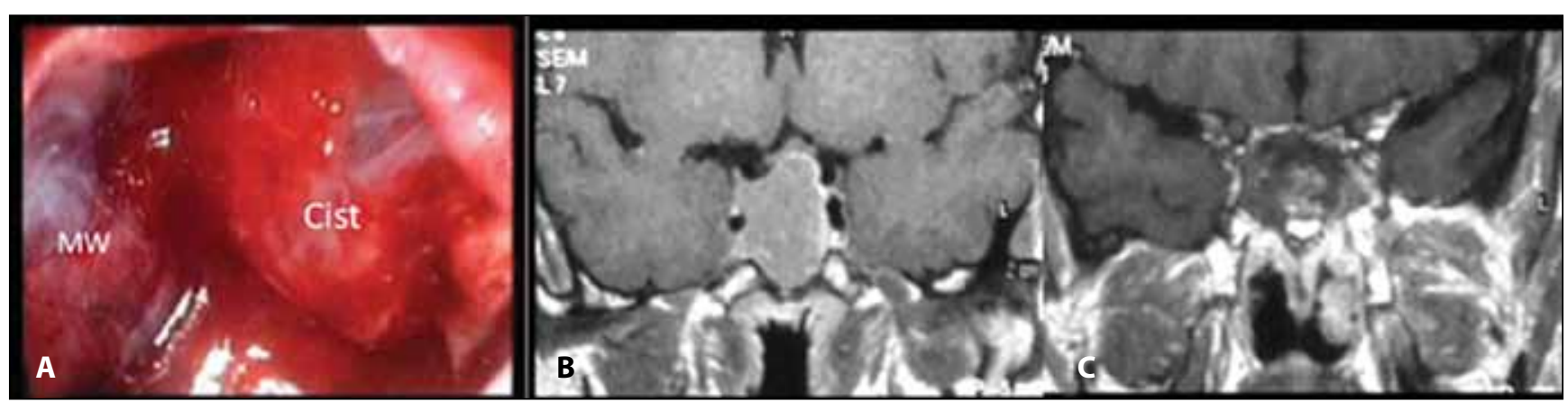

Figure 10: 45 year-old male with GH secreting adenoma. A) Intraoperative view of the case demonstrating cavernous sinus medial wall. Preoperative B) and Postoperative C) Gd-enhanced, T1-weighted MR images of the patient with Knosp grade 2. Absence of Cavernous Sinus invasion was demonstrated by the endoscopic technique.

MW: Medial wall of the Cavernous Sinus, Cist: Suprasellar Cistern.

\section{CONCLUSION}

Cavernous sinus invasion criteria were defined and pituitary adenomas classified according to their corridor involvement in this study. This classification was confirmed with the endoscopic surgical technique. Isolated lateral corridor involvement, which was not evaluated by neuroimaging techniques previously, was defined. Invasion - extension and cavernous sinus medial wall involvement is best demonstrated by the endoscopic technique. However, further anatomical studies are required for the confirmation of endoscopic clinical observations.

\section{ACKNOWLEDGMENT}

We thank Assoc. Prof. Volkan ETUS of our Department of Neurosurgery, Kocaeli University, School of Medicine, KocaeliTurkey, for preparing the illustrated drawings.

\section{REFERENCES}

1. Alfieri A, Jho HD: Endoscopic endonasal cavernous sinus surgery: An anatomic study. Neurosurgery 48(4): 827-836, 2001

2. Alfieri A, Jho HD: Endoscopic endonasal approaches to the cavernous sinus: Surgical approaches. Neurosurgery 49: 354-362, 2001

3. Cavallo LM, Cappabianca P, Galzio R, laconetta G, de Divitiis E, Tschabitscher M: Endoscopic transnasal approach to the cavernous sinus versus transcranial route: Anatomic study. Neurosurgery 56 (2 Suppl):379-389, 2005

4. Cappabianca P, Cavallo LM, Esposito F: Endonasal approaches to the cavernous sinus, in Anand VK, Schwartz TH (eds): Practical Endoscopic Skull Base Surgery. San Diego: Plural Publishing, 2007:177-190

5. Castelnuovo P, Pistochini A, Locatelli D: Different surgical approaches to the sellar region: Focusing on the "two nostrils four hands technique." Rhinology 44:2-7, 2006

6. Ceylan S, Koc K, Anik I: Extended endoscopic approaches for midline skull-base lesions. Neurosurg Rev 32 (3): 309-319, 2009
7. Ceylan S, Koc K, Anik I: Endoscopic endonasal transsphenoidal approach for pituitary adenomas invading the cavernous sinus. J Neurosurg: 112(1): 99-107, 2010

8. Chi JG, Lee MH: Anatomical observations of the development of the pituitary capsule. J Neurosurg 52:667-670, 1980

9. Ciric I: On the origin and nature of the pituitary gland capsule. J Neurosurg 46:596-600, 1977

10. Cottier JP, Destrieux C, Brunereau L, Bertrand P, Moreau L, Jan M, Herbreteau D: Cavernous sinus invasion by pituitary adenoma: MR imaging. Radiology 215:463-469, 2000

11. Couldwell WT, Sabit I, Weiss MH, Giannotta SL, Rice D: Transmaxillary approach to the anterior cavernous sinus: A microanatomic study. Neurosurgery 40:1307-1311,1997

12. Das K, Spencer W, Nwagwu Cl, Schaeffer S, Wenk E, Weiss $\mathrm{MH}$, Couldwell WT: Approaches to the sellar and parasellar region: Anatomic comparison of endonasal-transsphenoidal, sublabialtranssphenoidal,and transethmoidal approaches. Neurol Res 23:51-54, 2001

13. Doglietto F, Lauretti L, Frank G, Pasquini E, Fernandez E, Tschabitscher M, Maira G: Microscopic and endoscopic extracranial approaches to the cavernous sinus: Anatomic study. Neurosurgery 64: (5 Suppl 2):413-421; discussion 421-422, 2009

14. Dolenc VV: Relation of the cavernous sinus to the sella, in Dolenc VV (ed): Anatomy and Surgery of the Cavernous Sinus. Vienna: Springer- Verlag, 1989:118-130

15. Dolenc VV: Anatomy and surgery of the cavernous sinus. Berlin, Springer, 1989

16. Dolenc VV:Transcranial epidural approach to pituitary tumors extending beyond the sella. Neurosurgery 41: 542-550, 1997

17. Fahlbusch $R$, Buchfelder M: Transsphenoidal surgery of parasellar pituitary adenomas. Acta Neurochir (Wien) 92: 93-99, 1988

18. Fahlbusch R, Buchfelder M, Nomikos P: Management Options in the treatment of Invasive Pituitary Tumors; the Cavernous Sinus: A Comprehensive Text. M B Eisenberg, O Al- Mefty (Eds): Philadelphia: Lippincott Williams and Wilkins, 2000: 291-295 
19. Frank G, Pasquini E: Endoscopic endonasal approaches to the cavernous sinus: Surgical approaches. Neurosurgery 50:675, (comment), 2002

20. Frank G, Pasquini E: Endoscopic Endonasal Cavernous Sinus Surgery, with Special Reference to Pituitary Adenomas: Laws ER Jr, Sheehan JP (eds): Pituitary Surgery - A Modern Approach:Front Horm Res. Basel: Karger, 2006:64-82 (vol 34)

21. Jho HD, Ha HG: Endoscopic endonasal skull base surgery: Part 2-the cavernous sinus. Minim Invasive Neurosurg 47: 9-15, 2004

22. Jho HD, Ha HG: Endoscopic endonasal skull base surgery: Part 3 -the clivus and posterior fossa. Minim Invasive Neurosurg 47:16-23, 2004

23. Kassam A, Snyderman CH, Mintz A, Gardner P, Carrau RL: Expanded endonasal approach: The rostrocaudal axis. Part I. Crista galli to the sella turcica. Neurosurg Focus 19(1): E3, 2005

24. Knosp E, Steiner E, Kitz K, Matula C: Pituitary adenomas with invasion of the cavernous sinus space: A magnetic resonance imaging classification compared with surgical findings. Neurosurgery 33:610-618, 1993

25. Peker S, Kurtkaya-Yapicier O, Kiliç T, Pamir MN: Microsurgical anatomy of the lateral walls of the pituitary fossa. Acta Neurochir (Wien) 147(6):641-648; discussion 649, 2005
26. Songtao $Q$, Yuntao $L$, Jun $P$, Chuanping $H$, Xiaofeng $S$ : Membranous layers of the pituitary gland histological anatomic study and related clinical issues. Neurosurgery 64: (3 Suppl):1-9; discussion 9-10, 2009

27. Trouillas J, Daniel L, Guigard MP, Tong S, Gouvernet J, Jouanneau E, Jan M, Perrin G, Fischer G, Tabarin A, Rougon G, Figarella-Branger D: Polysialylated neural cell adhesion molecules expressed in human pituitary tumors and related to extrasellar invasion. J Neurosurg 98: 1084-1093, 2003

28. Yasuda A, Campero A, Martins C, Rhoton AL Jr, Ribas GC: The medial wall of the cavernous sinus: Microsurgical anatomy. Neurosurgery 55:179-190, 2004

29. Yilmazlar S, Kocaeli H, Aydiner F, Korfali E: Medial portion of the cavernous sinus: Quantitative analysis of the medial wall. Clin Anat 18(6): 416-422, 2005

30. Yokoyama S, Hirano H, Moroki K, Goto M, Imamura S, Kuratsu $\mathrm{J}$ : Are nonfunctioning pituitary adenomas extending into the cavernous sinus aggressive and/or invasive? Neurosurgery 49:857-863, 2001

31. Vieira JO Jr, Cukiert A, Liberman B: Evaluation of magnetic resonance imaging criteria for cavernous sinus invasion in patients with pituitary adenomas: Logistic regression analysis and correlation with surgical findings. Surg Neurol $65: 130-135,2006$ 